\title{
DÜBLIN
}

Technological University Dublin ARROW@TU Dublin

\section{How Things Grow: Gabriel Orozco's Samurai Tree: Invariants (2005)}

\section{Tim Stott}

Technological University Dublin, tim.stott@tudublin.ie

Follow this and additional works at: https://arrow.tudublin.ie/aaschadpart

Part of the Art and Design Commons

\section{Recommended Citation}

Stott, T. (2017). ow Things Grow: Gabriel Orozco's Samurai Tree: Invariants (2005), Art Journal, Fall. doi:10.21427/D75T82

This Article is brought to you for free and open access by the Fine Arts at ARROW@TU Dublin. It has been accepted for inclusion in Articles by an authorized administrator of ARROW@TU Dublin. For more information, please contact arrow.admin@tudublin.ie, aisling.coyne@tudublin.ie,gerard.connolly@tudublin.ie.

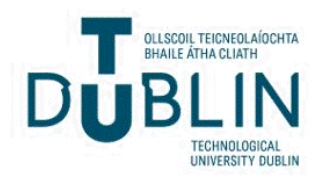


Dublin Institute of Technology

ARROW@DIT

Articles

Conservatory of Music and Drama

$2017-10$

\section{How Things Grow: Gabriel Orozco’s Samurai Tree: Invariants (2005)}

Tim Stott

Follow this and additional works at: http://arrow.dit.ie/aaconmusart

Part of the Contemporary Art Commons, and the Theory and Criticism Commons

This Article is brought to you for free and open access by the Conservatory of Music and Drama at ARROW@DIT. It has been accepted for inclusion in Articles by an authorized administrator of ARROW@DIT. For more

information, please contact yvonne.desmond@dit.ie, arrow.admin@dit.ie. 


\section{How Things Grow: Gabriel Orozco's The Samurai Tree: Invariants (2005) \\ Tim Stott}

With the exhibition Structures, Systems and Chance at the Serpentine Gallery, London, from 1 July to 31 August 2004, the Mexican artist Gabriel Orozco made an unexpected departure from the sculptural works, drawings, and photographs with which he came to prominence in the early 1990s and presented a number of abstract paintings, mostly acrylic on canvas. Orozco was unsure of their status. Viewed as paintings, they would disappoint, he warned. Instead, they would function as diagrams to explain 'how things work, how objects behave, and how plants grow.' For Briony Fer, Orozco took a risk with these works, because an 'established vocabulary for painting in some way fails to fit [them].' It is this insight by Fer that I want to develop here, by asking what is the nature of the risk Orozco takes with this series of works and in what way do they function as diagrams of organic growth. I focus on one body of work in particular, The Samurai Tree: Invariants, based upon the composition of two of the paintings on show at the Serpentine, The Samurai's Tree and Spinning and Rotating, both 2004. These are just a few of several investigations Orozco has made into arrangements of circular motifs. For Invariants, with the aid of a computer Orozco worked out all possible variations of the four-colour arrangements that result from the operations implicit in the two earlier paintings, producing a series of six hundred and seventy-two numbered inkjet prints in combinations of red, blue, white, and gold, first exhibited as a full set at Museum Ludwig in Cologne from 3 November 2006 to 28 January 2007. Concurrent with the exhibition, Walther König published a book of the complete set of prints.

I argue that the risk Orozco takes with Invariants, both as a series of prints and as a book, is, first, to build its organisation upon a set of distinctly ornamental procedures, and second, to then present the results of these procedures as diagrams. To understand Invariants, therefore, we must abandon the common characterisation of ornament as a supplement and decorative embellishment that lacks any structural function, and attend instead to its constructive, even diagrammatic role, however unconventional these roles might appear. 